\title{
Dietary long chain $n-3$ polyunsaturated fatty acid induced regulatory T-cells contribute to the prevention of oral sensitization to cow's milk protein in mice
}

\author{
L Van Den Elsen ${ }^{1 *}$, B van Esch ${ }^{1,2}$, G Hofman ${ }^{1}$, B van de Heijning ${ }^{2}$, J Garssen 1,2, L Willemsen ${ }^{3}$ \\ From Food Allergy and Anaphylaxis Meeting (FAAM 2013) \\ Nice, France. 7-9 February 2013
}

\section{Background}

Cow's milk allergy is one of the most common food allergies in children. Dietary lipid composition may affect the susceptibility to develop allergic diseases. Aim of this study was to assess whether and how dietary supplementation with long chain $n-3$ polyunsaturated fatty acids ( $n-3$ LCPUFA) prevents the establishment of food allergy.

\section{Methods}

Donor mice were fed a control or fish oil diet before and during oral sensitization with whey. Acute allergic skin response, serum immunoglobulins as well as dendritic cell (DC) and T-cell subsets in mesenteric lymph nodes (MLN), spleen and/or small intestine were assessed. Besides serum transfer experiments, adoptive transfer experiments with splenocytes of whey-sensitized donor mice fed a control or fish oil diet were performed. For this purpose naïve recipient mice received splenocytes either or not ex vivo depleted of CD25+ cells, or MACS isolated CD4+CD25+ regulatory T-cells (Treg). Recipient mice were sham- or whey-sensitized and fed control diet.

\section{Results}

The acute skin response as well as whey-IgE and -IgG1 levels were reduced in sensitized donor mice fed the fish oil diet as compared to the control diet. Serum transfer confirmed the Th2 type humoral response to be suppressed since sera of fish oil fed sensitized mice had a

${ }^{1}$ Utrecht Institute for Pharmaceutical Sciences, Utrecht University, Utrecht, the Netherlands

Full list of author information is available at the end of the article diminished capacity to induce an allergic response in naïve recipient mice compared to control sera. Furthermore, the acute skin response was diminished upon passive sensitization with hyperimmune serum in fish oil fed naïve recipient mice indicating suppression of the effector response by n-3 LCPUFA. Fish oil fed wheysensitized donor mice showed an increased \% Treg inducing CD11b+CD103+CD8 $\alpha-D C$ in MLN in association with enhanced FoxP3+ Treg in spleen and intestine compared to sham mice. In whey-sensitized recipient mice transferred with splenocytes from wheysensitized fish oil fed donor mice, the acute allergic skin response was similar to sham-sensitized recipients. $E x$ vivo depletion of Treg prevented this transfer of tolerance. Transfer of CD4+CD25+ Treg (85\% was FoxP3+) from fish oil fed whey sensitized donors prevented the acute allergic skin response most pronounced.

\section{Conclusion}

Dietary n-3 LCPUFA largely prevent allergic sensitization in a mouse model for cow's milk allergy by suppressing the humoral response, enhancing local and systemic Treg and reducing acute allergic symptoms. FoxP3+ Treg play an important role in whey allergy prevention by $\mathrm{n}-3$ LCPUFA.

\section{Disclosure of interest}

L Van Den Elsen: None declared, B van Esch: Employee of Danone Research, G Hofman: None declared, B van de Heijning: Employee of Danone Research, J Garssen: Employee of Danone Research, L Willemsen: None declared. 


\section{Author details}

${ }^{1}$ Utrecht Institute for Pharmaceutical Sciences, Utrecht University, Utrecht, the Netherlands. ${ }^{2}$ Danone Research, Wageningen, the Netherlands. ${ }^{3} U$ trecht University, Utrecht, the Netherlands.

Published: 25 July 2013

doi:10.1186/2045-7022-3-S3-018

Cite this article as: Van Den Elsen et al:: Dietary long chain $n-3$

polyunsaturated fatty acid induced regulatory T-cells contribute to the prevention of oral sensitization to cow's milk protein in mice. Clinical and Translational Allergy 2013 3(Suppl 3):018.

Submit your next manuscript to BioMed Central and take full advantage of:

- Convenient online submission

- Thorough peer review

- No space constraints or color figure charges

- Immediate publication on acceptance

- Inclusion in PubMed, CAS, Scopus and Google Scholar

- Research which is freely available for redistribution

Submit your manuscript at www.biomedcentral.com/submit
() Biomed Central 